\title{
Transport infrastructure of the Yamalo-Nenets Autonomous Okrug as a guarantee of the region's sustainable economic development
}

\author{
Anna Ermakova ${ }^{1, *}$ and Ekaterina Glebova ${ }^{1}$ \\ ${ }^{1}$ Industrial University of Tyumen, 625001, Tyumen, Russia
}

\begin{abstract}
This article considers the transport infrastructure of the city district as one of the most promising areas today. The existing problems of the road transport network are identified. The author offers a draft solution and the necessary costs for its implementation. This project will increase the flow of motor transport, provide comfortable pedestrian and automobile zones, and improve the socio-economic situation of the city district.
\end{abstract}

\section{Introduction}

Thanks to the convenient transport scheme, the city district of Labytnangi is an organizational and economic center for the development of natural resources of the Yamal Peninsula, which serves as a transport and transshipment hub.

The problem of high-quality roads is relevant today not in small cities, but also in the country as a whole. The effectiveness of the project lies primarily in the comfortable living and movement of residents of the Labytnangi urban district, as the territory is surrounded by a public and business zone, an external transport zone and a sports zone [1].

Currently, the city district of Labytnangi does not have a road connection with the Russian Federation's road network [2].

On the territory of the urban district of Labytnangi pass:

- a section of the public highway of inter - municipal significance Labytnangi-Harp, corresponding to the class "ordinary highway", category IV, with a length of $25.6 \mathrm{~km}$ within the boundaries of the urban district;

- a section of a public highway of inter - municipal significance Salekhard-Labytnangi, corresponding to the class "ordinary highway", category IV, with a length of $5.3 \mathrm{~km}$ within the boundaries of the city district;

- section of the winter highway Labytnangi - Muzhi - Azov - Tags.

For communication with the city of Salekhard, there is a ferry crossing over the $\mathrm{Ob}$ river in the summer. In winter, the Salekhard - Labytnangi winter road operates.

The internal transport scheme is a developed network of streets, roads and driveways in the built-up part of the city, providing the necessary transport links between the city's districts.

${ }^{*}$ Corresponding author: ermakovaa@tyuiu.ru 
The internal transport scheme is a poorly developed, fragmentary network of streets and driveways. The main traffic is carried out on the Labytnangi - Harp highway, Khanmeyskoe highway, Kovalev street, Polyarnaya street, Orlova street.

In accordance with the lists of public roads of local significance, objects of the street and road network of the municipality of Labytnangi, approved By the decree of the administration of the city of Labytnangi dated 11.02.2016 No. 87, the total length of the street and road network is $87.739 \mathrm{~km}$, of which $65.306 \mathrm{~km}$ with an improved type of pavement.

The maintenance of the city's street and road network is provided by: in terms of maintaining roads and squares-limited liability company "Reskom - Tyumen", in terms of lighting city roads and territories-limited liability company "Energoinvest".

The traffic flow on the street and road network of the Labytnangi city district includes all types of urban transport: passenger, cargo, public (buses and minibuses), motor transport, trailers and semi-trailers. The specific weight of each type in the total traffic flow is shown below (figure 1).

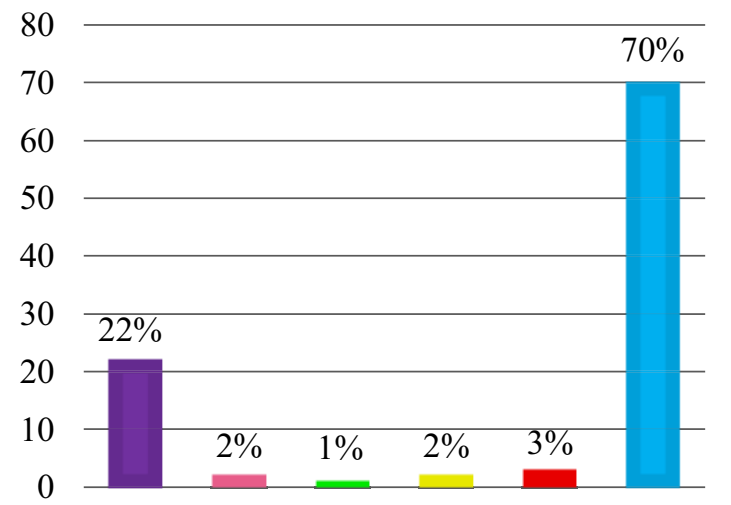

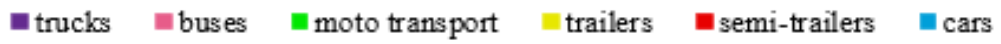

Fig. 1. The composition of traffic.

In recent years, there has been a steady trend to increase the number of cars in the territory of the city district of Labytnangi. The fleet of vehicles is replenished mainly due to the growth in the number of cars and trucks [3].

The situation of road transport infrastructure allows us to conclude that there are a number of transport problems in the territory of the city district of Labytnangi presented in figure 2 .

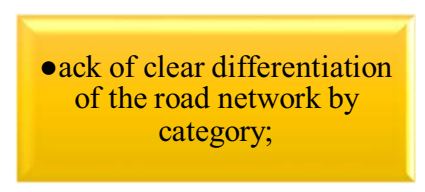

-low level of provision with equipped storage places;
- lack of capital-type road pavements on some streets;

- has no road connection with the road network of the Russian Federation.

Fig. 2. Problems of transport support. 
Recently, large-scale works have been launched in Labytnangi on Yamal. In addition to the new houses, there will be a comfortable road with lighting, sidewalks, and Parking lots that will relieve the yard territories from cars [4]. Courtyards should be safe for children to play in. All engineering networks are laid underground so that nothing interferes with the passage and cleaning of territories from snow. This year, the reconstruction of the longest Ob street in the city will be completed [5].

Many road reconstruction activities are planned for 2020 and 2021. as can be seen from table 1, the most expensive program was the reconstruction of Orlova street with a cost of 191548.89 rubles.

Table 1. Financial expenses for the implementation of municipal program activities.

\begin{tabular}{|c|c|c|c|c|c|}
\hline \multirow{2}{*}{$\begin{array}{l}\text { Activities of } \\
\text { the municipal } \\
\text { program }\end{array}$} & \multirow{2}{*}{$\begin{array}{c}\text { Responsible } \\
\text { executor/co- } \\
\text { executor }\end{array}$} & \multirow{2}{*}{$\begin{array}{l}\text { Sources of } \\
\text { funding }\end{array}$} & \multicolumn{3}{|c|}{$\begin{array}{c}\text { Financial costs for implementation } \\
\text { (thousand rubles) }\end{array}$} \\
\hline & & & Total & 2020 year & 2021 year \\
\hline \multirow{4}{*}{$\begin{array}{lr}\text { Reconstruction } \\
\text { of } & \text { Orlova } \\
\text { street } & \text { mkrn. } \\
\mathrm{Ob} & \end{array}$} & \multirow{4}{*}{$\begin{array}{l}\text { Administration of } \\
\text { Labytnangi, "UKS } \\
\text { Labytnangi» }\end{array}$} & Total & 191548.89 & 191548.89 & - \\
\hline & & $\begin{array}{l}\text { budget of } \\
\text { the } \\
\text { Autonomous } \\
\text { region }\end{array}$ & 181971.45 & 181971.45 & - \\
\hline & & $\begin{array}{l}\text { the budget } \\
\text { of the city } \\
\text { district }\end{array}$ & 9577.44 & 9577.44 & - \\
\hline & & $\begin{array}{l}\text { other } \\
\text { sources }\end{array}$ & - & - & - \\
\hline \multirow{4}{*}{$\begin{array}{l}\text { Reconstruction } \\
\text { of the highway } \\
\text { from Orlova } \\
\text { street to the } \\
\text { road to the city } \\
\text { of Labytnangi }\end{array}$} & \multirow{4}{*}{$\begin{array}{l}\text { Administration of } \\
\text { Labytnangi, "UKS } \\
\text { Labytnangi» }\end{array}$} & Total & 79418.43 & 79418.43 & - \\
\hline & & $\begin{array}{l}\text { budget of } \\
\text { the } \\
\text { Autonomous } \\
\text { region }\end{array}$ & 75447.51 & 75447.51 & - \\
\hline & & $\begin{array}{l}\text { the budget } \\
\text { of the city } \\
\text { district }\end{array}$ & 3970.92 & 3970.92 & - \\
\hline & & $\begin{array}{l}\text { other } \\
\text { sources }\end{array}$ & - & - & - \\
\hline \multirow{4}{*}{$\begin{array}{l}\text { Reconstruction } \\
\text { of streets in } \\
\text { the Central }\end{array}$} & \multirow{4}{*}{$\begin{array}{l}\text { Administration of } \\
\text { Labytnangi, "UKS } \\
\text { Labytnangi» }\end{array}$} & Total & 133918.13 & - & 133918.13 \\
\hline & & $\begin{array}{l}\text { budget of } \\
\text { the } \\
\text { Autonomous } \\
\text { region }\end{array}$ & 127222.22 & - & 127222.22 \\
\hline & & $\begin{array}{l}\text { the budget } \\
\text { of the city } \\
\text { district }\end{array}$ & 6695.91 & - & 6695.91 \\
\hline & & $\begin{array}{l}\text { other } \\
\text { sources }\end{array}$ & - & - & - \\
\hline \multirow[b]{2}{*}{$\begin{array}{l}\text { Reconstruction } \\
\text { of the street } \\
\text { Gullies }\end{array}$} & \multirow[b]{2}{*}{$\begin{array}{l}\text { Administration of } \\
\text { Labytnangi, "UKS } \\
\text { Labytnangi» }\end{array}$} & Total & 85220.63 & - & 85220.63 \\
\hline & & $\begin{array}{l}\text { budget of } \\
\text { the } \\
\text { Autonomous } \\
\text { region }\end{array}$ & 80959.60 & - & 80959.60 \\
\hline
\end{tabular}

In addition to road reconstruction, major and ongoing repairs are being carried out. In total, 20 road sections and driveways with a total length of more than $6 \mathrm{~km}$ will be repaired in 2020. Traditionally, repairs will affect those areas that are most often mentioned in citizens ' appeals. 
Figure 3 shows a cartogram of the speed of passenger cars.

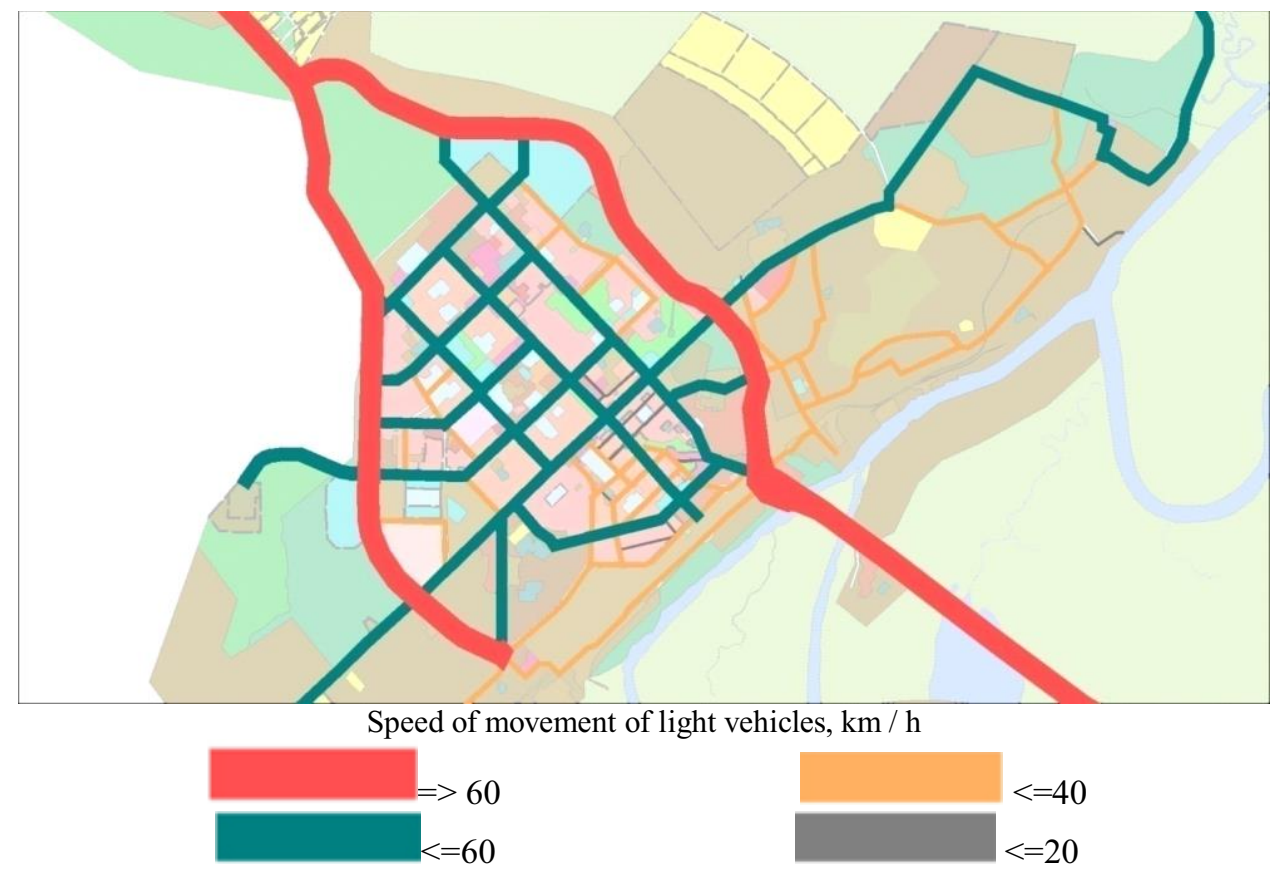

Fig. 3. Cartogram of the speed of passenger cars.

Road reconstruction means, first of all, changing the road surface

The purpose of the study is to improve the transport and operational characteristics of the existing road network in the city of Labytnangi.

The object of the study is "The highway along Sovetskaya street in the suburb of Labytnangi [6].

The design area is located in the South-Western part of the municipality of Labytnangi. The total design area is 39,124 . 00 sq. m. The total length of the road section, within the design boundaries, is $0.79401 \mathrm{~km}$.

\section{Materials and methods}

The planned territory is located in the alignment of the existing Sovetskaya street. Stateowned land is located within the boundaries of the project before the division of rights to land and land plots of various forms of ownership [7].

The project provides for the reconstruction of Sovetskaya street in the area from Lesnaya street to Oktyabrskaya street, Zheleznodorozhnaya, Tsentralnaya and Pervomayskaya streets, as well as the Square within the boundaries of the above-mentioned streets $[8,9]$. The design and construction of the projected section of the highway is planned to be carried out in two stages.

The projected sections of Zheleznodorozhnaya, Tsentralnaya, and Pervomaiskaya streets are main streets of district significance that are part of the Labytnangi city road network, providing transport and pedestrian links between adjacent residential buildings and the city's business centers, and have access to other main streets and roads in the network. According to the terms of reference for design work (see figure 4), functional purpose (according to SP 42.13330.2011, vol. 7) and forecast data for the estimated 
intensity for the last year of road service projected sections of Railway, Central, Pervomayskaya - main street of district significance, pedestrian and transport.

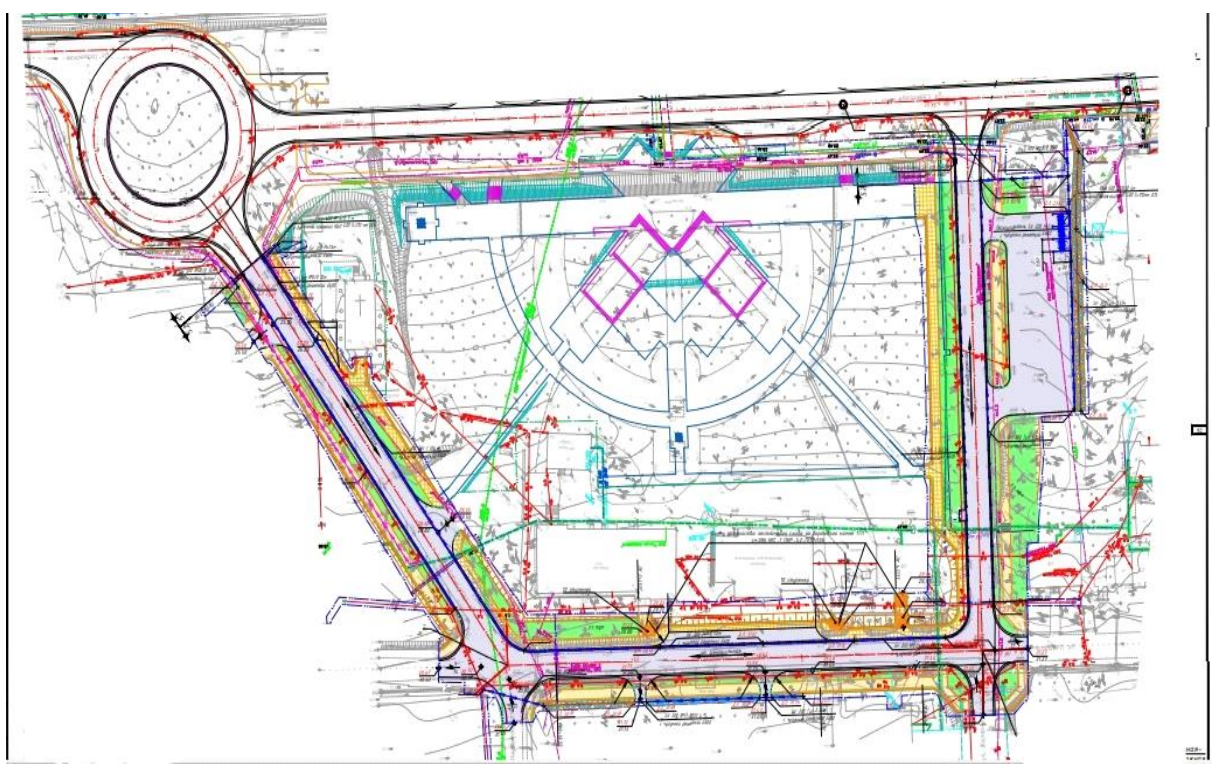

Fig. 4. Reconstruction of the object "Highway along Sovetskaya street in Labytnangi. Square ".

Table 2. Symbols for figure 3.

\begin{tabular}{|c|c|}
\hline Table of symbols & Explanations \\
\hline \\
\hline
\end{tabular}

The planned section of Railroad street, Central street and Pervomayskaya street - main streets of district significance of pedestrian traffic, part of the existing road network of the 
city of Labytnangi and provides Hiking trails and the Beginning of the design corresponds to:

- PK 0+00,00 (street Railway) corresponds to the center of the intersection of the street Railway street Central;

- PC $0+00,00$ (Tsentralnaya street) corresponds to the center of the intersection Pervomayskaya street - Tsentralnaya street;

- PC $0+00,00$ (Pervomayskaya street) corresponds to the axis of the "roundabout"designed in The framework of stage 5.1.

The end of the projected routes corresponds to:

- PK 1+59.51 (Zheleznodorozhnaya street) corresponds to the axis of the projected section of Sovetskaya street;

- PK 1+61.45 (Tsentralnaya street) corresponds to the center of the intersection Zheleznodorozhnaya street - Tsentralnaya street;

- PK 1+67.44 (Pervomayskaya street) corresponds to the center of the intersection Pervomayskaya street - Tsentralnaya street.

The total length of the route is $0.48840 \mathrm{~km}$. The General direction is South-East, SouthWest and West.

Table 3. Characteristics of a linear item.

\begin{tabular}{|c|c|c|}
\hline Name & $\begin{array}{c}\text { Unit of } \\
\text { measurement }\end{array}$ & Indicators \\
\hline Type of construction & - & reconstruction \\
\hline Technical category & - & $\begin{array}{c}\text { Main street of regional significance } \\
\text { pedestrian and transport }\end{array}$ \\
\hline Length of the design section & $\mathrm{km}$ & 0.79401 \\
\hline The estimated speed & $\mathrm{km} / \mathrm{h}$ & 50 \\
\hline Number of traffic lanes & pieces & 2 \\
\hline The width of the roadway & meters & $\begin{array}{c}8.0-\text { restricted conditions } \\
9.0-\text { normal conditions }\end{array}$ \\
\hline Sidewalk width & meters & 3.0 \\
\hline Width of the instrument panel & meters & 0.5 \\
\hline Bus stops & pieces & 20 \\
\hline Length of the stop platform & meters & South West \\
\hline The direction of the route & \multicolumn{2}{|c}{} \\
\hline \multicolumn{2}{|r}{}
\end{tabular}

According to the pre-project survey, the current traffic intensity as of 2019 is 5,362 vehicles per day. The estimated service life of the road surface in the I 3 road climate zone for category II public roads is 12 years. The estimated intensity for the last year of the service life is taken into account the growth rate of $1 \%$ and is 6012 vehicles/day for 2028 , of which:

- passenger transport - 4577 vehicles per day;

- cargo transport (light, up to 5 tons) - 785 vehicles per day;

- cargo transport (medium, 5-8 tons) - 392 vehicles per day;

- buses -258 cars per day.

\section{Results}

The accepted road surface structure is represented by the following structural layers (the total average thickness of the structure is $0.09 \mathrm{~m}$ ):

- existing road surface - asphalt concrete; 
- coating (bottom layer, leveling layer) - hot, dense, fine-grained polymer-asphalt concrete, type B, grade I, on polymer-bitumen binder PBV 300 (GOST 9128-2013), with an average thickness of $0.10 \mathrm{~m}$;

- coating (top layer) - crushed stone-mastic asphalt concrete Shma-15, on polymerbitumen binder PBV 300 (GOST 31015-2002), 0.05 m thick.

The contract price amounted to 157786000 .

\section{Discussion}

Any locality (city, village) needs proper formation of the road transport network, reconstruction of road surfaces [10,11].

Ways to reconstruct road surfaces:

- Complete disassembly of the existing road surface using the obtained material in the construction of new road surface, roadside reinforcement, construction of bypass roads, entrances, etc.

- Destruction of existing road pavement, especially layers of monolithic materials, and use it as the top layer of the base. In this case, it increases the probability of preventing the possibility of reflected cracks in the upper layers (cracks that repeat the existing ones in the old coating) $[12,13]$.

- Destruction of the existing road surface, its widening and strengthening with new material with the laying of the corresponding upper layers.

- Preservation of the existing road surface, its patching, hot, cold or combined regeneration of the asphalt concrete surface with subsequent laying of the reinforcement layer. Synthetic mesh can be used to prevent the appearance of reflected cracks $[14,15]$.

- Preservation of existing road surface, its widening, patching, hot, cold or combined regeneration, if necessary, laying of synthetic mesh and installation of a reinforcement layer $[16,17]$.

\section{Conclusion}

1. Currently, the city of Labytnangi, thanks to its convenient transport scheme, is an organizational and economic center for the development of natural resources of the Yamal Peninsula, which serves as a transport and transshipment hub.

2. The internal transport scheme is a developed network of streets, roads and driveways in the built-up part of the city, providing the necessary transport links between the districts of the city.

3. The task of maintaining roads is to preserve them and maintain their condition in accordance with the requirements for the operational condition allowed under the conditions of road safety at any time of the year.

Thus, the conducted research will allow:

- provide a comfortable pedestrian and automobile zone;

- increase the flow of road transport;

- improve the socio-economic situation of the city district;

- increase the region's competitiveness and economic growth;

- it will provide the most comfortable accommodation for the local population;

- make the aesthetic appearance of the city district as a whole more attractive.

\section{References}

1. A. Ermakova, T. Nurullina, Moscow economic magazine 10, 49 (2019) 
2. A. Ermakova, Moscow Economic Journal 10, 50 (2019)

3. A. Ermakova, International Agricultural Journal 1, 20 (2021)

4. A. Ermakova, Y. Zubareva, Agrarian Bulletin of the Urals 8, 70-71 (2013)

5. A. Ermakova, Moscow economic magazine 10, 41 (2019)

6. E. Leshnevskaya, A. Ermakova, A. Popov, Agro-industrial complex: regions of Russia 4, 59-61 (2012)

7. I.A. Filippova, A.M. Ermakova, L.N. Gabdrakhmanova et al, International Journal of Recent Technologi and Engineering 6, 998-1004 (2019)

8. L. Oznobihina, Moscow Economic Journal 1, 7 (2020)

9. A. Oznobihina, L. Oznobikhina, Moscow Economic Journal 1, 8 (2019)

10. O. Shakhova, L. Oznobikhina, Agro-food policy of Russia 9, 55-56 (2012)

11. L. Oznobikhina, Moscow Economic Journal 2, 20 (2020)

12. L. Oznobikhina, Bulletin of the State Agrarian University of the Northern Trans-Urals 1, 78-84 (2016)

13. L. Oznobikhina International Agricultural Journal 1, 23 (2021)

14. O. Shakhova, L. Oznobikhina, Bulletin of the Michurinsky State Agrarian University 1, 34-37 (2019)

15. Y. Zubareva, I. Pivovarova, The national composition of the self-employed population of Siberia (according to the results of the census of 1897) 3, 129-134 (2019)

16. Kirilova, O. Ustinova, Voprosy istorii 9, 34-44 (2019)

17. Pivovarova, Y. Putilina, Y. Zubareva, A. Mamadaliev, Russian Historical Journal 49(3), 1216-1223 (2018) 